\title{
Notas Sobre a Existência Dum Jurista Filólogo
}

\author{
Alexandre Augusto de Castro Corrêa \\ Catedrático de Direito Romano da Faculdade \\ de Direito da Universidade de São Paulo *
}

Escrevo sobre o meu pai sob o aspecto das relaçōes intelectuaís que me uniram a ele, deixando à margem o relato das relações oriundas de vida familiar a qual, aliás, transcorreu sempre em invariável atmosfera de paz, harmonia e intensa afeição recíproca.

Minha formação jurídica e filosófica se fez tanto nas Faculdades de Direito da Universidade de São Paulo e de Filosofia da São Bento quanto no lar, pois os ensinamentos paternos eu os hauria nos dois centros de vida e estudo.

Desde a mais tenra infância minhas irmãs e eu nos habituamos ao ambiente ao mesmo tempo austero e acolhedor da vasta biblioteca formada pelo pai durante toda a sua existência e abrangendo todos os assuntos da cultura geral, histórica, literatura antiga e moderna e filosofia.

A parte jurídica embora menor era selecionada. Aprendi com meu pai a admirar e freqüentar «O Direito nas Coisas» de Lafayete Rodrigues Pereira e as obras de Teixeira de Freitas; quanto ao Direito Romano desde o início do curso jurídico familiarizei-me com as obrass de Savigny, Jhering, Windscheid e Mommsen, em edições tanto alemãs quanto francesas bem como com os trabalhos dos grandes italianos Ferrine, Bonfante, Arangro-Ruiz, De Francisci, etc.

Quanto a Ruy Barbosa, meu pai o tinha em altíssima conta enquanto conhecedor nímio da língua e dos clássicos por'ugueses. Aprendi com ele a respeitar o grande orador e escritor.

Das literaturas modernas, a francesa depois da portuguesa e brasileira parecia predominar na formação mental de meu pai, apesar de seu gosto por Goethe e Schiller e da admiração por Shakespeare $€$ Dickens. Nesse ponto meu pai não fez exceção à regra da infância cultural predominantemente francesa no Brasil até à Segunda Guerra Mundial.

Conhecia perfeitamente Molière, Corneille e Racine e náo escondia seu entusiasmo por Bossuet. Em geral o século de Luis XIV representava para ele o apogeu da literatura francesa. 
A filosofia, entretanto, sob todas as suas formas, foi a preocupação dominante da vida intelectual de meu pai: conhecia perfeitamente os gregos, especialmente Aristóteles estudando mais de perto por causa de sua influência sobre São Tomás na Idade Média, mas, também os modernos, desde Descartes até Kant, ele os expunha com admirável clareza em suas aulas.

Em tal ambiente e inclusive devido a meu curso de filosofia em São Bento fiquei marcado pela vida especulativa e pretendi, a prin cípio, especializar-me em Kant e no idealismo alemão, sobretudo de Hegel sem abandonar entretanto o confronto com a Neo-escolástica. A influência, porém, de minha mãe orientou-me para a advocacia e para o Direito: suceder um dia a meu pai na cátedra de Direito Romano pareceu-me, afinal, mais atraente, embora eu não estivesse, por temperamento, destinado a triunfar na profissão preferindo o ensino do direito, como de fato preferi.

Decisivo, também, nesse rumo, foi meu longo contato äe recém-formado com o Professor Gaetano Sciascia, então jovem romanista da Universidade de Roma, convidado por meu pai para colaborar com ele na cátedra da fundação da Faculdade de Direito da PUC.

Sciascia induziu-me a traduzir os Comentários de Gaio, trabalho que durante dois anos constituiu para mim a grande iniciação no estudo das fontes do Direito Romano e que desde aquela época nunca abandonei: a clareza lapidar dos textos e a sabedoria essencialmente humana dos jurisconsultos de Roma são valores imperecíveis que aprendi a apreciar num processo educativo incessante.

A formação do verdadeiro espírito jurídico e não apenas a produção de leguleios só se pode obter pela escola do Direito Romano: é uma conviç̧ão minha, herança do espírito paterno e frutificada por minha própria experiência.

Eis, em suma, o que posso dizer de Alexandre Correia como professor e estudioso: praticou acima de tudo a cultura geral, incluindo o Direito, dentro de sua visão de vida amplamente humanística e cristã. Assim o vejo e orgulho-me da ventura de ter convivido com ele durante sua longa e fecunda existência de noventa e quatro anos.

Acredito sinceramente que imitar-lhe o exemplo é o melhor modo de contribuir para a educação intelectual e moral de nossa juventude, abrindo-lhe o caminho para a verdadeira grandeza da pátria. 